\title{
Knowledge regarding the prevention of chronic kidney disease in hypertensive and diabetic patients: a cross-sectional study
}

\author{
Conhecimento sobre a prevenção da Doença Renal Crônica \\ em hipertensos e diabéticos: estudo transversal
}

\author{
Elaine Cristina Santa Cruz de Moura, Jefferson Belarmino Nunes Barbosa, \\ Patrícia Érika de Melo Marinho*
}

Universidade Federal de Pernambuco (UFPE), Recife, PE, Brazil

\begin{abstract}
Introduction: Hypertension (HT) and diabetes mellitus (DM) lead to functional and structural changes in target organs such as the kidneys, characterizing the need for preventive actions to avoid Chronic Kidney Disease (CKD). Objective: To verify cardiologists' and endocrinologists' knowledge, indications and practices regarding prevention of CKD in patients with HT and DM. Methods: A cross-sectional study with 14 cardiologists and 5 endocrinologists applying a questionnaire about the conduct of these professionals regarding the prevention of CKD in hypertensive and diabetic patients. Results: One hundred percent of the cardiologists and endocrinologists did not request specific tests for CKD screening (albuminuria and glomerular filtration rate (GFR), although $92.9 \%$ of the cardiologists and $60.0 \%$ of the endocrinologists report referring hypertensive and diabetic patients with impaired renal function to nephrologists. One hundred percent of the interviewees recognize the importance of physical exercise for their patients; however, only $68.6 \%$ of cardiologists and $60 \%$ of endocrinologists indicated a physiotherapist and/or physical trainer to implement these exercises. Conclusion: The professionals evaluated in this study do not request microalbuminuria and GFR examinations for hypertensive and diabetic patients as a follow-up routine, despite having found cases of renal function impairment in these patients; in contrast to what is proposed in the guidelines for hypertension and diabetes mellitus. They recognize the importance of physical exercise and report
\end{abstract}

* ECSCM: BS, e-mail: elainecsm2@gmail.com

JBNB: Master student, e-mail: jb_nunes1987@yahoo.com.br

PEMM: PhD, e-mail: patmarinho@yahoo.com.br 
indicating their patients to a physiotherapist and/or physical trainer. We suggest continuing the study in order to ascertain the reasons for their not complying with the respective guidelines.

Keywords: Disease Prevention. Comprehensiveness in Health Care. Chronic Disease. Hypertension. Diabetes Mellitus.

\section{Resumo}

Introdução: A hipertensão arterial (HAS) e o diabetes mellitus (DM) ocasionam alterações funcionais e estruturais de órgãos alvo como os rins, caracterizando a necessidade de ações preventivas para evitar a Doença Renal Crônica (DRC). Objetivo: Verificar o conhecimento, indicação e prática de condutas dos cardiologistas e endocrinologistas quanto a prevenção de DRC em pacientes com HAS e DM. Métodos: Estudo transversal realizado com 14 cardiologistas e 5 endocrinologistas, através de questionário referente a conduta desses profissionais quanto a prevenção da DRC entre hipertensos e diabéticos. Resultados: Cem por cento dos cardiologistas e endocrinologistas não solicitam os exames específicos para o rastreamento da DRC (albuminúria e estimativa da taxa de filtração glomerular - TGF), embora 92,9\% dos cardiologistas e 60,0\% dos endocrinologistas relatem encaminhar pacientes hipertensos e diabéticos com comprometimento da função renal ao nefrologista. Cem por cento dos entrevistados reconhecem a importância do exercício físico para seus pacientes, no entanto, apenas $68,6 \%$ dos cardiologistas e $60 \%$ dos endocrinologistas indicam o fisioterapeuta e ou educador físico para a realização dos mesmos. Conclusão: Os profissionais avaliados neste estudo não solicitam exames microalbuminúria e de TFG para pacientes hipertensos e diabéticos como rotina de acompanhamento, embora tenham encontrado casos de comprometimento da função renal nesses pacientes, diferentemente do proposto nas diretrizes para hipertensão arterial e diabetes mellitus. Reconhecem a importância do exercício físico e referem indicar seus pacientes ao fisioterapeuta e ou educador físico. Sugerimos continuidade do estudo a fim de averiguar as razões para o não cumprimento das respectivas diretrizes.

Palavras-chave: Prevenção de Doenças. Integralidade em Saúde. Doença Crônica. Hipertensão Arterial. Diabetes Mellitus.

\section{Introduction}

Cardiovascular and metabolic diseases are responsible for a high frequency of hospitalizations, leading to high medical and socioeconomic costs (1). In this sense, systemic hypertension (HT) and diabetes mellitus (DM) are considered multifactorial clinical conditions, frequently associated with population growth and aging, and an increasing prevalence of obesity and sedentary lifestyle, which can cause functional and/or structural alterations of target organs such as the heart, brain, blood vessels, and kidneys $(2,3)$.

The development of Chronic Kidney Disease (CKD) is frequently associated with HT and DM, which are the main causes of chronic renal failure in patients undergoing dialysis programs (2 - 5).

An important determining factor of renal function changes is the presence of albumin in the urine, initially represented by microalbuminuria or incipient nephropathy, and macroalbuminuria, proteinuria or clinical nephropathy in a more advanced stage $(3,6-8)$.

The clinical evaluation of these patients should take into account the risk factors and the possibility of lesions in the target organs, which can be obtained through laboratory tests such as creatinine clearance, glomerular filtration rate and microalbuminuria to characterize the severity of renal disease $(2,3)$.

In the case of patients with HT and DM, periodic laboratory tests for monitoring and tracing renal disease are necessary for early detection or to treat the disease in case of its occurrence $(2,3)$.

In view of the Brazilian guidelines for hypertension and diabetes, renal disease screening should be initiated soon after HT or DM diagnosis, and it should be performed annually based on albuminuria levels and an estimation of the glomerular filtration rate $(2,3)$. 
As the risk of CKD in patients with HT and DM is higher, early diagnosis of this disease needs to be performed as soon as possible, especially by cardiologists and endocrinologists who periodically attend these patients $(2,9)$. However, although this preventive measure is necessary considering the high prevalence of HT and DM, clinical control also requires regular practice of physical exercise, since it promotes reduced blood pressure, thus improving glycemic control and reducing glycated hemoglobin, characterized an important measure for preventing HT and DM complications $(2,3,10)$.

Considering that CKD is recognized as a global public health problem that is underdiagnosed, inadequately treated, and that once developed may lead to increasing medical and hospital care expenses (11 - 14), an evaluation regarding the technical knowledge and academic training of cardiologists and endocrinologists on managing/treating patients with HT and DM can elucidate how these patients are recognized as potential candidates for developing CKD.

In view of the above, the present study aimed to verify whether the guidelines for CKD prevention in patients with Systemic Hypertension (HT) and Diabetes Mellitus (DM) are being developed according to the respective guidelines $(2,3)$, as determined by cardiologists and endocrinologists of a high complexity hospital with the purpose of evaluating renal function and the practice of physical exercise.

\section{Methods}

A cross-sectional, analytical, quantitative study was carried out in a high complexity hospital unit, in the period of July to November 2014.

The present study was approved by the institutional research ethics committee in accordance with resolution 466/2012 of the National Health Council (CNS) protocol 26461313.7.0000.5208.

After a survey carried out in the human resources sector, 31 cardiologists and 10 endocrinologists were identified in this hospital. After clarification and signing informed consent forms, 14 cardiologists and 5 endocrinologists in regular exercise of their duties and duly registered at the referred hospital participated in the study.

Data were collected in a single step from elaboration of a semi-structured questionnaire for each specialization, containing the same questions and specifically designed for this study using questions regarding the knowledge and practice of conducts in accordance with the Brazilian Guidelines for Hypertension (Diretrizes Brasileiras de Hipertensão) (2) and the guidelines from the Brazilian Diabetes Society (Sociedade Brasileira de Diabetes) (3).

The initial part of the questionnaire was characterized by knowledge regarding academic training, degree (residency in the area) and workplace (public/private), followed by obtaining specific data regarding the preventive action of physicians regarding the request for preventive exams, detection/screening for renal function impairment and referral to the nephrologist, as well as data related to performing physical exercise and referral to professionals who treat patients with physical exercises (physiotherapist and physical trainer).

The present study considered the recognition of renal disease as adequate based on a request of exams for albuminuria and an estimation of glomerular filtration rate, as recommended by the HT and DM guidelines; identification of patients' renal function changes by these professionals; referral follow-up by the nephrologist; and referral of the patient to a physical exercise program by a physiotherapist and/ or physical trainer.

\section{Statistica I analysis}

An evaluation of the characteristics of the evaluated professionals was presented as percentage frequencies and frequency distributions. Chi-square test for homogeneity was performed in order to compare the behavior of cardiologists and endocrinologists regarding their patient's renal function and physical activity evaluation. Fisher's exact test was applied in cases where the assumptions of the chi-square test were not met. All conclusions were made considering a significance level of 5\%. A database was built in a Microsoft Excel spreadsheet which was exported to the SPSS version 18.0 program to analyze the data.

\section{Results}

Of the 41 volunteers eligible to participate in the study, only 22 professionals were contacted and 19 of these completed the study, being 14 cardiologists and 5 endocrinologists (Figure 1). 


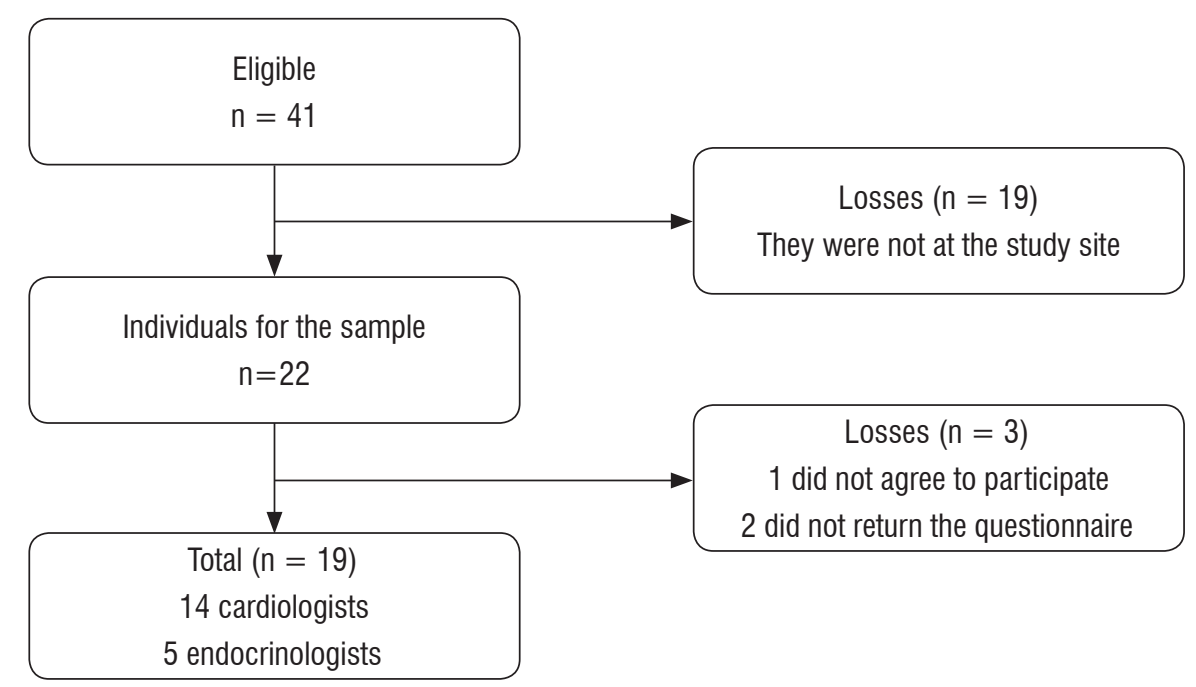

Figure 1 - Flowchart of patients in the study.

Table $\mathbf{1}$ - Characteristics of cardiologists and endocrinologists regarding their age, academic background and workplace

\begin{tabular}{lccc}
\hline Evaluated factor & N & $\%$ & p-value \\
\hline $\begin{array}{l}\text { Specialization/occupation } \\
\quad \text { Endocrinologist }\end{array}$ & 5 & 26.3 & 0.039 \\
$\quad$ Cardiologist & 14 & 73.7 & \\
$\begin{array}{l}\text { Residency } \\
\quad \text { Yes }\end{array}$ & 18 & 94.7 & \\
$\quad$ No & 1 & 5.3 & $<0.001$ \\
Years of Completion after residency & & & \\
$\quad 0$ to 5 years & 4 & 21.1 & \\
$\quad 5$ to 10 years & 2 & 10.5 & 0.004 \\
$\quad 10$ or more & 13 & 68.4 & \\
Workplace & & & \\
$\quad$ Public & 6 & 31.6 & 0.108 \\
$\quad$ Public and private & 13 & 68.4 & \\
\hline
\end{tabular}

Note: Considering $\mathrm{p}$-value $<0.05$.
Table 2 presents the results regarding the evaluation of renal function. All cardiologists and endocrinologists reported encountering cases of impaired renal function; $57.1 \%$ of the cardiologists and $60 \%$ of the endocrinologists reported rarely finding this occurrence. According to the questionnaire responses, both groups reported requesting laboratory tests for their hypertensive and diabetic patients for CKD prevention; however, none of these professionals requested glomerular filtration rate (GFR) nor albuminuria; moreover, the frequency in which laboratory tests were requested, including urea and creatinine, ranged from one to three times a year.

According to the presented answers, $92.9 \%$ of the cardiologists and $60.0 \%$ of the endocrinologists responded referring these patients to nephrologists as soon as they detected cases of impaired renal function (Table 2).

Table 2 - Characteristics regarding the evaluation of renal function between cardiologists and endocrinologists

\begin{tabular}{|c|c|c|c|}
\hline \multirow[t]{2}{*}{ Evaluated factor } & \multicolumn{2}{|c|}{ Medical specialization } & \multirow[t]{2}{*}{ p-value } \\
\hline & Cardiologist & Endocrinologist & \\
\hline \multicolumn{4}{|c|}{$\begin{array}{l}\text { Usually require laboratory tests to evaluate the renal function of their } \\
\text { diabetic patients }\end{array}$} \\
\hline Yes & $14(100.0 \%)$ & $5(100.0 \%)$ & - \\
\hline Requests GFR and & & & \\
\hline
\end{tabular}


Table 2 - Characteristics regarding the evaluation of renal function between cardiologists and endocrinologists

\begin{tabular}{lccc}
\hline Evaluated factor & \multicolumn{2}{c}{ Medical specialization } & \multirow{2}{*}{ p-value } \\
\cline { 2 - 3 } & Cardiologist & Endocrinologist & \\
\hline No & $14(100.0 \%)$ & $5(100.0 \%)$ & - \\
How often they usually request exams & & & \\
$\quad$ Once a year & $5(41.7 \%)$ & $1(20.0 \%)$ & \\
$\quad$ Twice a year & $4(33.3 \%)$ & $2(40.0 \%)$ & 0.818 \\
$\quad$ Three times a year & $3(25.0 \%)$ & $2(40.0 \%)$ & \\
Usually encounter cases of impaired renal function in their patients & & & \\
$\quad$ Yes & $14(100.0 \%)$ & $5(100.0 \%)$ & \\
How often they usually find these cases in the outpatient clinic & & & \\
$\quad$ Rarely & $8(57.1 \%)$ & $2(40.0 \%)$ & 0.628 \\
$\quad$ Regularly & $6(42.9 \%)$ & $3(60.0 \%)$ & \\
Type of conduct after encountering kidney disease & & & \\
$\quad$ Adequate & $13(92.9 \%)$ & $3(60.0 \%)$ & 0.155 \\
\hline
\end{tabular}

Note: Fisher's exact test, $p$ value $<0.05$.

When questioned about the importance of practicing physical exercise, $100 \%$ of professionals in each specialization reported believing that physical exercise can be indicated for their patients, indicating the practice and giving instructions when they do not have a place or someone to refer the patients; moreover, they usually observe changes over time in patients who exercise.

Sixty-eight point six percent (68.6\%) of cardiologists and $60 \%$ of endocrinologists reported indicating a physical therapist and/or a physical trainer to instruct physical exercises for their patients, both in public and private services (Table 3 ).

Table 3 - Characteristics of physical exercise evaluation between cardiologists and endocrinologists

\begin{tabular}{|c|c|c|c|}
\hline \multirow[t]{2}{*}{ Evaluated factor } & \multicolumn{2}{|c|}{ Medical specialization } & \multirow[t]{2}{*}{$\mathrm{p}$-value } \\
\hline & Cardiologist & Endocrinologist & \\
\hline \multicolumn{4}{|c|}{ Physical exercise can be indicated for their patients } \\
\hline Yes & $14(100.0 \%)$ & $5(100.0 \%)$ & - \\
\hline \multicolumn{4}{|c|}{ Do you usually indicate physical exercise for your patients? } \\
\hline Yes & $14(100.0 \%)$ & $5(100.0 \%)$ & - \\
\hline \multicolumn{4}{|c|}{ Referral for a Physical Therapist/Trainer } \\
\hline Adequate & $11(78.6 \%)$ & $3(60.0 \%)$ & 0.570 \\
\hline \multicolumn{4}{|c|}{ Service indicated for the practice of physical activity } \\
\hline Private & $3(30.0 \%)$ & $0(0.0 \%)$ & \multirow{2}{*}{0.505} \\
\hline Public and private & $7(70.0 \%)$ & $5(100.0 \%)$ & \\
\hline \multicolumn{4}{|c|}{ Gives guidance on the subject if they have nobody to refer them to } \\
\hline Yes & $14(100.0 \%)$ & $5(100.0 \%)$ & - \\
\hline \multicolumn{4}{|c|}{ There is a change over time in patients who exercise } \\
\hline Yes & $14(100.0 \%)$ & $5(100.0 \%)$ & - \\
\hline
\end{tabular}

Note: Fisher's exact test, $p$ value $<0.05$. 


\section{Discussion}

According to the results presented, it can be observed that the cardiologists and endocrinologists evaluated in the present study report requesting exams for evaluating renal function of hypertensive and diabetic patients respectively; however, the tests considered adequate for this purpose are not properly requested. One hundred percent of cardiologists and endocrinologists reported indicating physical exercise practice for their patients, however, only $78.6 \%$ and $60 \%$ of these respectively refer them to appropriate professionals. All physicians recognized an improvement in the physical condition of their patients who follow physical exercise programs.

Although cardiologists and endocrinologists evaluated in our study require periodic laboratory tests for hypertensive and diabetic patients, it is still necessary to include albuminuria and GFR exams in their routines. Other studies carried out in Senegal (13), Spain (14) and the United States (15) show that hypertension and DM are the main diseases that pose a risk of developing kidney damage, and that these diseases require preventive screening through laboratory tests, not only in adults but also in children in order to avoid developing $\operatorname{CKD}(16,17)$.

CKD prevention in at-risk patients should be performed to treat and control modifiable risk factors such as diabetes and hypertension, and their control and treatment must be in accordance with the regulations and guidelines of Brazilian Guidelines for Hypertension and Diabetes which were used as the basis for this study $(2,3)$.

Our results indicate that cardiologists and endocrinologists request laboratory tests for their patients, however, they do not request microalbuminuria tests or glomerular filtration rate estimates. We do not know whether these professionals are unaware of which tests are considered for diagnosis of renal disease, or whether they do not use them due to operational difficulties in the service. In evaluating renal function at the primary care level, Pena et al. (16) identified that only $8.1 \%$ and $4.8 \%$ of primary care physicians requested measurement of GFR among diabetics and hypertensives patients attending family health centers respectively, demonstrating the need for more requests of preventive exams by these professionals, especially in services that seek prevention $(3,18)$.
Albuminuria and GFR are renal function tests that identify and classify renal disease severity and are considered predictors of mortality and of decline in renal function in the general population. Therefore, the recommendation is that the request for these tests should be performed annually for patients who are at risk of developing kidney disease $(5,18,19)$.

Regarding the referral of hypertensive and or diabetic patients to a nephrologist, most cardiologists and more than half of the endocrinologists reported making the referral upon detecting altered renal function. In another study, more than half of the physicians $(51.2 \%)$ referred patients presenting a mild/moderate GFR reduction to the nephrologist, and $25.8 \%$ of the physicians did not refer patients with Chronic Kidney Disease to the specialist (16). According to the Brazilian Society of Diabetes, the screening should be annual and be based on albuminuria measurement and glomerular filtration estimation (3).

Appropriate treatment is based on three pillars of support: early diagnosis, immediate referral for nephrological treatment, and implementation of measures to preserve renal function. Of the three pillars, immediate referral of patients for followup by the nephrologist or the nephrology team was positively verified in the conduct observed in the physicians of our study (9).

Regarding the practice of regular physical exercise, the present study showed that cardiologists and endocrinologists believe that physical exercise may be indicated for their patients, and that in addition to indicating this practice they also give guidelines if they have no place or person they can refer the patients to. These professionals reported that they tend to observe changes over time in patients who exercise.

The guidelines recommend that in order to maintain good cardiovascular health and quality of life, every adult should perform physical exercise three to five times a week, with 30 minutes of light to moderate physical activity (18). In the case of established kidney disease, Martinez-Castelao et al. reported that exercise should be adapted to the individual's physical capacity (14).

In our study, most cardiologists and endocrinologists reported giving instructions and indicating physical activity for their patients to both public and private services. The importance 
of physical exercise practice is recognized by the physicians of our study who are aware that exercise can have a positive impact on many of the health problems, especially hypertension (20 - 23).

The present study did not investigate the possible reasons for not requesting microalbuminuria or GFR exams by these professionals, which was a partial limitation, but at the same time also points out the need for continuity of the study for future clarifications. Another aspect that deserves to be further investigated is patient's acceptance regarding an indication for exercise programs that these professionals referred, since their access is difficult in practice.

This has been one of the first studies to focus on clinical and endocrinological follow-up of hypertensive and diabetic patients regarding the possible development of CKD. Although the guidelines considered in this study highlight the importance of specific laboratory follow-up for CKD screening, we have observed that this reality is not yet fully developed in the high complexity hospital investigated.

The importance of these results for physical therapy is evident. Firstly, it provides physiotherapists the need to instruct hypertensive and diabetic patients about the necessity to perform tests that accompany the evolution of their underlying diseases, as well as enabling these professionals to guide and develop physiotherapeutic treatment programs for clinical control. Secondly, it is evident that despite being guided by cardiologists and endocrinologists, patients may not attribute the real importance of engaging in targeted physical exercise programs. The presence of a physiotherapist may be decisive in raising patients' awareness regarding the importance of participating in exercise programs.

\section{Conclusion}

Cardiologists and endocrinologists identified in the present study have found cases of impaired renal function in patients with HT and DM, and reported requesting preventive laboratory tests. However, the requested tests did not meet the requirements for kidney disease diagnosis in its different stages according to the guidelines for each specialization. Regarding the indication for practicing physical exercise, they reported indicating a physiotherapist and/or physical trainer.

We suggest that further studies be developed to ascertain the reasons why screening for CKD in patients with hypertension and diabetes mellitus has not been duly performed according to the specific guidelines of these diseases.

\section{References}

1. Bielemann RM, Knuth AG, Hallal PC. Atividade física e redução de custos por doenças crônicas ao Sistema Único de Saúde. Rev Bras Ativ Fís Saúde. 2010;15(1):9-14.

2. Sociedade Brasileira de Cardiologia / Sociedade Brasileira de Hipertensão / Sociedade Brasileira de Nefrologia. VI Diretrizes Brasileiras de Hipertensão. Arq Bras Cardiol. 2010;95(1 Suppl 1):1-51.

3. Diretrizes da Sociedade Brasileira de Diabetes 20142015 [cited 2015 Jan 15]. Available from: https:// tinyurl.com/ljozgef.

4. Moreira HG, Sette JBC, Keiralla LCB, Alves SG, Pimenta E, Sousa M, et al. Diabetes Mellitus, Hipertensão Arterial e Doença Renal Crônica: estratégias terapêuticas e suas limitações. Rev Bras Hipertens. 2008;2(15):111-6.

5. Moraes CE, Cerolli CF, Silva VS, Franco RJS, Habermann F, Matsubara BB, et al. Preditores de insuficiência renal crônica em pacientes de centro de referência em hipertensão arterial. Rev Assoc Med Bras. 2009;55(3):257-62.

6. Mendes RS, Bregman R. Avaliação e Metas do Tratamento da Proteinúria. Rev Bras Hipertens. 2010;3(17):174-7.

7. Krolewski AS, Bonventre JV. High Risk of ESRD in Type 1 diabetes: New strategies are needed to retard progressive renal function decline. Semin Nephrol. 2012;5(32):407-14.

8. Roett MA, Liegl S, Jabbarpour Y. Diabetic NephropatyThe Fammily Physician's Role. Am Fam Physician. 2012;9(85):883-9. 
9. Bastos MG, Kirsztajn GM. Doença renal crônica: importância do diagnóstico precoce, encaminhamento imediato e abordagem interdisciplinar estruturada para melhora do desfecho em pacientes ainda não submetidos à diálise. J Bras Nefrol. 2011;33(1):93-108.

10. Diretriz de reabilitação cardiopulmonar e metabólica: aspectos práticos e responsabilidades. Arq Bras Cardiol. 2006;86(1):74-82.

11. Capilheira M, Santos IS. Desempenho no Cuidado Médico de Doenças Crônicas Não Transmissíveis. Cad Saúde Pública. 2011;27(6):1143-53.

12. Czeresnia D. Ações de promoção à saúde e prevenção de doenças: o papel da ANS. Rio de Janeiro: ANS; 2003. $35 \mathrm{p}$.

13. Seck SM, Doupa D, Gueye L, Dia CA. Epidemiology of chronic kidney disease in northern region of Senegal: a community-based study in 2012. J Pan Afr Med. 2014;16(18):1-8.

14. Martínez-Castelao A, Górriz JL, Bover J, Segura MJ, Cebollada J, Escalada Jr, et al. Documento de consenso para la detección y manejo de la enfermedad renal crónica. Nefrología (Madr.). 2014;34(2):243-62.

15. Vieira Jr JM, Suassuna JHR. Acometimento renal na hipertensão arterial e diabetes mellitus tipo 2: como identificar e prevenir. A visão do nefrologista. Rev HUPE. 2013;1(12):53-60.

16. Pena PFA, Silva Jr AG, Oliveira PTR, Moreira GAR, Braga AL. Cuidado ao paciente com Doença Renal Crônica no nível primário: pensando a integralidade e o matriciamento. Cienc Saúde Coletiva. 2012;17(11):3135-144.
17. Balat A. Children with Chronic Kidney Disease and Hypertension: Could Hypertension Footprints be Early Biomarkers? Rev Curr Hypertens. 2014;10(2):86-98.

18. Matos SA, Pádua MA, Schaan BD, Caramelli B, Rochitte CE, Serrano Jr CV, et al. I Diretriz sobre Aspectos Específicos de Diabetes (tipo 2) Relacionados à Cardiologia. Arq Bras Cardiol. 2014;102(5 Suppl 1):1-41.

19. Kitada M, Kanasaki K, Koya D. Clinical therapeutic strategies for early stage of diabetic kidney disease. World J Diabetes. 2014;5(3):342-56.

20. Smith AC, Burton JO. Exercise in kidney disease and diabetes: time for action. J Renal Care. 2012;38(1):52-8.

21. Medizin PI, Sportkardiologie K, Bedeutung R. Evidenz der körperlichen Aktivität zur Prävention und Therapie von Erkrankungen. Dtsch Med Wochenschr. 2013;138(44):2253-9.

22. Forge R. Physical Activity Guidelines for Diabetes and Prediabetes. IHS Division of Diabetes. A Web-based Training. 2013;2-25.

23. Hordern MD, Dunstan DW, Prins JB, Bakes MK, Singh MA, Coombes JS. Exercise prescription for patients with type 2 diabetes and pre-diabetes: A position statement from Exercise and Sport Science Australia. J Sci Med Sport. 2012;15:25-31.

Received in $02 / 14 / 2016$

Recebido em 14/02/2016

Approved in 04/04/2017

Aprovado em 04/04/2017 